\title{
Game-changers: dynamic capabilities' influence on service ecosystems
}

Suvi Nenonen, J ohanna Gummerus and Alexey Sklyar

The self-archived postprint version of this journal article is available at Linköping University Institutional Repository (DiVA):

http:// urn.kb.se/ resolve?urn=urn:nbn:se:liu:diva-150571

N.B.: When citing this work, cite the original publication.

Nenonen, S., Gummerus, J., Sklyar, A., (2018), Game-changers: dynamic capabilities' influence on service ecosystems, J ournal of Service Management, 29(4), 569-592. https:// doi.org/ 10.1108/J OSM02-2017-0025

Original publication available at:

https:// doi.org/ 10.1108/J OSM-02-2017-0025

Copyright: Emerald

http:// www.emeraldinsight.com/ 
Game-changers: dynamic capabilities’ influence on service ecosystems

Suvi Nenonen, (Graduate School of Management, Business School, University of Auckland, Auckland, New Zealand)

Johanna Gummerus, (Department of Marketing, Centre for Relationship Marketing and Service Management, Hanken School of Economics, Helsinki, Finland)

Alexey Sklyar, (Department of Management and Engineering, Linköping University, Linköping, Sweden)

This is the authors' preprint copy and some minor changes have occurred during the final publication phase. The published article is available here (cite this source when appropriate):

Suvi Nenonen, Johanna Gummerus, Alexey Sklyar, (2018) "Game-changers: dynamic capabilities' influence on service ecosystems", Journal of Service Management, Vol. 29 Issue: 4, pp.569-592, https://doi.org/10.1108/JOSM-02-2017-0025 


\begin{abstract}
Purpose - Service-dominant logic acknowledges that actors can influence how service ecosystems evolve through institutional work, but empirical research is only nascent. This paper advances understanding of ecosystem change by proposing that dynamic capabilities are a special type of operant resources enabling actors to conduct institutional work. Consequently, the purpose of this paper is to explore which dynamic capabilities are associated with proactively influencing service ecosystems.
\end{abstract}

Design/methodology/approach - Drawing on service-dominant logic, institutional work, and dynamic capabilities, this exploratory study assumes an actor-centric perspective and proposes a conceptual model with a hierarchy of dynamic capabilities as the antecedents for successfully influencing service ecosystems. The research model was tested with survey data using PLSSEM.

Findings - Among the dynamic capabilities studied, 'visioning' and 'influencing explicit institutions' directly affect 'success in influencing service ecosystems', whereas 'timing' does so indirectly through 'influencing explicit institutions'. The other dynamic capabilities studied have no significant effect on 'success in influencing service ecosystems'. 'Success in influencing service ecosystems' positively affects the 'increased service ecosystem size and efficiency'.

Practical implications - In addition to reactively positioning and competing at the marketplace, firms can choose to proactively influence their service ecosystems' size and efficiency. Firms aiming to influence service ecosystems should particularly develop dynamic capabilities related to visioning, timing, and influencing explicit institutions.

Originality/value - This research is the first service-dominant logic investigation of the linkage between the actors' dynamic capabilities and their ability to influence service ecosystems.

Keywords: service ecosystem, service-dominant logic, dynamic capabilities, institutional work, PLS-SEM 
Paper type: research paper 


\section{Game-changers: dynamic capabilities’ influence on service ecosystems}

\section{Introduction}

The context of value cocreation is increasingly conceptualized as a service system (Maglio et al., 2009; Ng et al., 2011, Chandler and Chen, 2016) or as a service ecosystem (Lusch et al., 2010; Akaka and Vargo, 2015). A service ecosystem is "a relatively self-contained, selfadjusting system of resource-integrating actors connected by shared institutional logics and mutual value creation through service exchange” (Lusch and Vargo, 2014, p. 24). Service ecosystems are akin to natural ecosystems in their ability to emerge and to go through profound changes over time (Mars et al., 2012; Lusch et al., 2016). However, service ecosystems differ from their natural counterparts in being influenced by actor-created institutions and institutional arrangements (Vargo and Lusch, 2016). Or, as Mars et al. (2012) suggest: actors in service ecosystems "create strategies and structures (e.g., institutions)" and thus "organizations can design and master-plan systems and networks” (p. 277). Therefore, service-dominant logic acknowledges that actors can influence how service ecosystems evolve, but also notes that there is a dire need for more research on the topic (Chandler and Lusch, 2015).

In order to understand this phenomenon better, service-dominant logic has recently turned to institutional work (Siltaloppi et al, 2016; Vargo and Lusch, 2016), which has a long tradition of investigating how actors can overcome the "paradox of embedded agency" and influence the institutions surrounding them (Battilana et al., 2009; Garud et al., 2007; Lawrence and Suddaby, 2006). However, Wilden et al. (2017) conclude in their recent systematic literature review that "ecosystems" and "institutions" do not yet appear as distinct themes in the service-dominant logic corpus, indicating that the related conceptual development is still in its infancy, and warranting more research.

Institutional work is commonly depicted as actions that actors conduct to create, maintain and disrupt institutions (cf., Koskela-Huotari et al., 2016; Vargo and Lusch, 2016). 
But what is the "action" referred to, exactly? As Vargo et al. (2015) conclude, our understanding of institutionalization processes in socio-technical systems is only nascent. Most of the current research either focuses on a very particular context (cf., Palmer et al., 2015) or provides diverging lists of numerous actions related to institutional work. For example, Lawrence and Suddaby (2006) propose nine forms of institutional work to create institutions, six forms to maintain institutions, and three forms to disrupt institutions, whereas Battilana and D’Aunno (2009) put forward 21 forms of institutional work that are largely different from Lawrence and Suddaby’s (2006). Thus, more work is needed to develop a conceptually clear and parsimonious platform for theorizing.

An alternative way to approach institutional work can, however, be detected in servicedominant logic and its concept of operant resources, which encompass actors' competencies and capabilities (Karpen et al., 2015). As all capabilities concern the ability of actors to perform activities (Collis, 1994), these operant resources could be a durable way of explaining nonroutinized action - such as institutional work - that is also compatible with service-dominant logic. This rationale is also in line with management literature, where Eisenhardt and Martin (2000, p. 11) connected dynamic capabilities with resource integration and changing the surrounding system, emphasizing that dynamic capabilities entail "the processes to integrate, reconfigure, gain and release resources — to match and even create market change”. More recent dynamic capabilities literature similarly highlights the connection between capabilities and actors' ability to influence service ecosystems. Teece (2007, pp. 1319-1320) argues that dynamic capabilities “embrace the enterprise's capacity to shape the ecosystem it occupies”. Dynamic capabilities provide, therefore, a micro-level foundation for the institutional work done by actors.

Building on the above discussion, the present research conceptualizes dynamic capabilities as a special case of operant resources underlying the institutional work done by actors. Therefore, the research question for this exploratory study is: which dynamic capabilities 
are associated with proactively influencing service ecosystems? This research question also responds to Wilden et al. (2017), who explicitly call for future research integrating servicedominant logic and dynamic capabilities to develop a strategic approach to service-dominant logic.

Next, the paper discusses the literature related to service ecosystem change and dynamic capabilities. This theoretical background informs the conceptual framework, which is then tested empirically. Finally, the paper closes with conclusions to theory and managerial practice, as well as limitations and avenues for further research.

\section{Conceptual background}

\section{Service ecosystem change}

What is known about actors' ability to influence ecosystems and the eventual role that dynamic capabilities play in this? Previous conceptual work on service-dominant logic has framed firms as actors in dyads (micro-level), triads (meso-level), or networks (macro-level), and treated firms as actors influencing the system through multiple exchanges and resource integration (Chandler and Vargo, 2011). In turn, Siltaloppi et al. (2016) highlight the role of cocreation, since those authors, referring to Giddens, indicate that "institutions and institutional arrangements in service ecosystems can be seen to have only virtual existence that is inseparable from actors and their enactment of value cocreation practices, which produces and reproduces the institutional structure” (p. 336).

Despite the emphasis placed on actors and cocreation, recent research on service ecosystems change has mainly increased understanding of how change takes place at the system level. Aal et al. (2016) conclude that values resonance - the degree to which actors' foundational values (i.e., the normative and cultural-cognitive elements) are compatible - is both an enabler and a prerequisite for innovation to take place in service ecosystems. Chandler and Chen (2016) investigate micro-macro links in the service systems, and show that micro- 
level practices shift in response to event triggers and that these practice shifts translate to changes at the service system level. Meynhardt et al. (2016) similarly focus on micro-macro dynamics and put forward systemic principles of value cocreation, which detail how selforganization and emergence take place on the service ecosystem level.

Understanding of how individual actors aim to influence the development of service ecosystems is, however, much scanter. Current empirical investigations of how actors influence service ecosystems in practice tend to be limited to case studies (cf., Storbacka and Nenonen, 2011; Koskela-Huotari et al., 2016). Storbacka and Nenonen (2011) propose that focal actors can offer market (service ecosystem) propositions which engage other actors in creating a shared market (service ecosystem) view - which consecutively may translate to corresponding changes in the mental and business models of all actors in the ecosystem. Koskela-Huotari et al. (2016) in turn apply institutional work to four cases depicting innovation in service ecosystems, and find evidence of interdependent breaking, making, and maintaining of institutions in each of the cases. However, their study concerns the "institutionalized rules of resource integration” - particularly implicit norms - rather than the strategies directed at shaping the explicit institutions of the ecosystem such as laws or infrastructures. Beyond these two pieces of research, authors are unaware of studies informed by service-dominant logic that investigate individual actors’ deliberate attempts to influence service ecosystems.

\section{Dynamic capabilities and service-dominant logic}

Adopting a focal actor perspective, as is done in this paper, allows the use of theories and frameworks that focus on the activities of an individual actor, such as business models and institutional work above. This paper proposes the use of a particular actor-specific lens dynamic capabilities.

The concept of dynamic capabilities was introduced by Teece et al. (1997), drawing on

the resource-based view (Wernerfelt, 1984; Barney, 1991). In their investigation of the 
evolution and prospects of service-dominant logic, Wilden et al. (2017) highlight dynamic capabilities as one of the dominant change-related theories in management and call for future research integrating dynamic capability and service-dominant logic perspectives. The authors of the present paper concur, and propose that dynamic capabilities literature offers promising avenues for investigating change driven by individual actors - such as institutional work.

However, introducing new concepts to an established theory or framework should be done with full awareness of their underlying assumptions. When considering the compatibility of dynamic capabilities with service-dominant logic, three themes warrant particular awareness: 1) outcomes explained; 2) analytical level; 3) reactive vs. proactive approach. First, in terms of the outcomes explained, dynamic capabilities literature has been mainly interested in outcomes for the focal firm (e.g., financial performance, competitive advantage), whereas servicedominant logic advocates value creation to the beneficiary and the service ecosystem viability. However, the fourth foundational premise of service-dominant logic states that "operant resources are the fundamental source of strategic benefit” (Vargo and Lusch, 2016, p. 8), highlighting that service-dominant logic can also be used to understand outcomes for a particular actor. Furthermore, the recent service-dominant logic research suggests that the theoretical backdrop of dynamic capabilities, resource-based view (RBV), may be more compatible with service-dominant logic than previously thought. Drawing on Priem and Butler (1991), Peters (forthcoming) argues that RBV implicitly assigns primacy to the demand side, i.e., adopts beneficiary perspective.

Second, regarding the analytical level, service-dominant logic explicitly allows investigations on micro, meso and macro levels (Vargo and Lusch, 2016). Original literature on dynamic capabilities was primarily interested in understanding micro-level dynamics, whereas the more recent developments explicitly acknowledge the interdependence of actors, and that the actors' dynamic capabilities have the potential to influence the larger surrounding system (e.g., Teece, 2007; Wilden et al., 2016). 
Third, a corresponding change has been observed in the reactive vs. proactive orientation. Initial conceptualizations treated dynamic capabilities largely reactive, whereas the more recent dynamic capabilities literature increasingly acknowledges the ability of dynamic capabilities to proactively induce system-level change (e.g., Pitelis and Teece, 2010; Wilden et al., 2016). Thus, it can be concluded that dynamic capabilities literature is conceptually moving closer to service-dominant logic.

\section{Dynamic capabilities as micro-foundations for institutional work}

Due to their definitional link to change, dynamic capabilities appear to be particularly important to actors operating in dynamic contexts (Wilden and Gudergan, 2015). However, whether change is conceptualized as exogenous or endogenous seems to be a defining factor in researching dynamic capabilities. As discussed above, earlier work on dynamic capabilities focused on defining the concepts and explaining firm performance, and (often implicitly) emphasized firms’ ability to react to exogenous change (Wang and Ahmed, 2007; Pitelis and Teece, 2010; Wilden et al., 2016). However, based on a comprehensive analysis of the dynamic capabilities literature, Wilden et al. (2016) suggest that dynamic capabilities are configured to fit the actor's particular strategic orientation - and that the defining dichotomy in strategic orientations resides in reacting to changes in the service ecosystem (“being market-driven”) vs. proactively changing the service ecosystem (“being market-driving”).

This dichotomy also affects the applicability of perhaps the most widely used categorization of higher-order dynamic capabilities, namely that of Teece (2007). Whereas Teece (2007) proposes that dynamic capabilities enable firms to: 1) sense and shape opportunities and threats; 2) seize opportunities; and 3) continuously align and re-align their resource base, this view has since incurred criticism for being more oriented towards a marketdriven than a market-driving stance. For example, Wilden et al. (2016) suggest that sensing and 
seizing, which Teece (2007) proposes as two of the main dynamic capabilities, are more suitable for reactive (“market-driven”) organizations.

Due to the previous emphasis of the dynamic capabilities literature on reacting to ecosystem changes, it appears that many of the existing categorizations of dynamic capabilities - such as sensing, seizing, and reconfiguring - are not directly applicable in the context of proactively inducing change in the service ecosystem. Actors aiming to influence service ecosystems will need different dynamic capabilities, related to, for example, generating increased customer value, exploration, and risk-absorption (Wilden et al., 2016). Hence, there is great need for exploring the dynamic capabilities that drive ecosystem change.

Following the newer stream of dynamic capabilities literature, the present study draws from the definition of Barreto (2010), which delineates dynamic capabilities as a "firm's potential to systematically solve problems, formed by its propensity to sense opportunities and threats, to make timely and market-oriented decisions, and to change its resource base” (p. 271). In order to preserve the parsimony of the conceptual hierarchy and lexicon of service-dominant logic, the present study proposes that dynamic capabilities are a special case of operant resources, and that actors apply ecosystem-driving dynamic capabilities when they conduct institutional work. This is in line with Madhavaram and Hunt (2008), who suggested that dynamic capabilities can be viewed as operant resources, a stance also taken by Karpen et al. (2015). Thus, the present study adopts the following definition of dynamic capabilities: dynamic capabilities are operant resources, working upon other operand and operant capabilities, that allow actors to systematically influence resource integration and institutions. Investigating operant resources underlying institutional work can be considered a continuation of service-dominant logic's actor-to-actor perspective. Since service-dominant logic embraced the notion of generic resource-integrating actors without pre-fixed roles such as 'customer' and 'provider' (Kjellberg et al., forthcoming; Vargo and Lusch, 2011, 2016), it also recognized activities, resources and resource integration beyond the immediate monetized 
exchange of service and/or service rights (Peters, forthcoming). Resources ${ }^{1}$ and resource integration responsible for institutional work may not necessarily be market-facing, and thus they are often ignored by goods-dominant marketing. In contrast, service-dominant logic provides a coherent theoretical base for investigating such resources. However, it should be kept in mind that the value and "resourceness" of resources are always context dependent (Akaka and Vargo, 2014; Chandler and Vargo, 2011). Thus, dynamic capabilities responsible for institutional work in one context may not be operant resources - or resources at all - in another context.

\section{The proposed theoretical framework}

The link between dynamic capabilities and actors’ ability to induce change has already been acknowledged in the service-dominant logic literature on the micro level as some researchers have used dynamic capabilities to explain service innovations (cf., Agarwal and Selen, 2009; den Hertog et al., 2010; Menguc and Auh, 2006; Ordanini and Parasuraman, 2011). However, the meso and macro level effects of dynamic capabilities on service ecosystems remain largely unknown: to the best of the present authors' knowledge, no previous service-dominant logic research has investigated the linkage between actors' dynamic capabilities and their ability to influence service ecosystems.

As support for identifying those dynamic capabilities that shape ecosystems, this paper draws on the literature on dynamic capabilities (Teece, 2007; Pitelis and Teece, 2010; Wilden, 2016), and service-dominant logic (Madhavaram and Hunt, 2008; Lusch and Vargo, 2014; Siltaloppi et al., 2016). To date, the majority of dynamic capability researchers appear to agree that there are several types of capabilities, and that they exist at different orders, i.e., within a hierarchy of capabilities (Hine et al., 2014; Madhavaram and Hunt, 2008). While the original

\footnotetext{
${ }^{1}$ In the interest of readability, the paper will use the term 'dynamic capabilities' throughout the manuscript, when referring to operant resources underlying institutional work to influence service ecosystems.
} 
division was one between ordinary (non-dynamic) and dynamic capabilities (cf., Barreto, 2010), recently dynamic capabilities have been further divided into higher- and lower-order capabilities (Hine et al, 2014; Schilke, 2014). Nevertheless, the interaction between higher- and lower-order dynamic capabilities warrants more empirical research (Peteraf et al., 2013). Before discussing higher- and lower-order capabilities, the paper will first discuss the outcomes of ecosystem-shaping dynamic capabilities, i.e., the dependent variables of the proposed model.

\section{Outcomes of dynamic capabilities for service ecosystem change}

From a service ecosystem perspective, the relevant outcomes of higher- and lower-order capabilities are twofold. The first, direct outcome is success in influencing service ecosystems, which reflects actors' ability to deploy their dynamic capabilities. Second, if an actor is able to influence the service ecosystem, the overall ecosystem size and efficiency may increase (Narver and Slater, 1990; Baker and Sinkula, 1999; Jaworski et al., 2000, Kumar et al., 2000; Bharadwaj et al., 2005). This second, indirect outcome - increased overall ecosystem size and efficiency - only relates to the actor's dynamic capabilities if the actor is able to influence service ecosystems, and that outcome therefore has no direct relationship with the dynamic capabilities. Building on the above, the paper proposes that success in influencing service ecosystems is positively related to increased service ecosystem size (e.g., collective market size and value creation to customers) and efficiency (e.g., more efficient use of resources):

H1: Success in influencing service ecosystems is positively related to increased service ecosystem size and efficiency. 


\section{Dynamic capabilities driving service ecosystem change}

Identifying the dynamic capabilities that influence ecosystem change is more challenging than identifying the outcomes of dynamic capabilities on service ecosystem level, given the paucity of research on the interrelationships between dynamic capabilities and service ecosystems. Drawing upon a service-dominant logic view of actors as resource integrators (Vargo and Lusch, 2004; 2008), a dynamic capabilities view (Teece, 2007), and Barreto’s (2010) definition of dynamic capabilities, as well as Marquis and Raynard's (2015) work on institutional strategies, this paper suggests two central higher-order dynamic capabilities that drive ecosystem change: 'visioning' and 'timing'.

The concept of 'visioning' develops further the central capacity of sensing opportunities (Teece, 2007). However, unlike traditional sensing, which often refers to reacting to external opportunities, 'visioning' for inducing ecosystem-level change takes a proactive stance. 'Visioning' requires understanding of the ecosystem development trajectory, and hence it refers to the ability to predict future development of the ecosystem. 'Visioning' also requires foreseeing what kind of development is benevolent for the focal actor - and the ability to communicate and track this vision. This interpretation is in line with Zahra et al. (2006), who consider visioning as foundational to dynamic capabilities: "there is a need for managerial vision in thinking about the firm's competitive arena and the trajectory of its future evolution” (p. 944). Similarly, Wang and Ahmed (2007) point out that it is important to "maintain a consistent long-term vision” (p. 44). 'Visioning' captures institutional embeddedness in that it also reflects the firm's ability to navigate between alternative (institutional) logics (Greenwood and Suddaby, 2006). Hence, for the purposes of this paper 'visioning' refers to a particular higher-order capability related to service ecosystems change.

The second higher-order capability in play, 'timing', builds upon the ideas of Teece (2007), Eisenhardt and Martin (2000), and Lusch (2011), according to whom "it is more and more important to have speed and adaptability. Increasingly it is who learns and implements 
the quickest” (Lusch, 2011, p. 16). Many of the original references to 'timing' in dynamic capabilities literature emphasize the imperative of acting quickly (cf., Zott, 2003; Teece, 2007). However, when the objective is to influence service ecosystems, 'timing' also reflects attributes other than speed per se, in particular actors' ability to understand the ecosystem's speed of change and time their own actions accordingly. This forward-looking take on 'timing' echoes earlier studies, for example Day (1994), who suggested that "anticipation of future needs for capabilities” (p. 37) would be necessary for enhancement of capabilities, and Eisenhardt and Martin (2000), who argued that firms need to spot opportunities and act on them in a timely manner.

As discussed earlier, higher-order dynamic capabilities are those that have an indirect influence on performance (e.g., Zahra et al., 2006) through lower-order capabilities. Hence, this study hypothesizes that 'visioning' and 'timing' influence service ecosystems indirectly through the lower-order capabilities. Drawing on structuration theory (Giddens, 1984), Vargo and Akaka (2012) conceptualize service ecosystems as having a dual nature: consisting both of interconnected relationships between actors and of social structures such as rules and resources. Thus, this paper hypothesizes that service ecosystems can be influenced by altering resources available to actors, relationships between actors, and institutions. Based on the literature review, these pathways have been further developed into four lower-order dynamic capabilities: 'understanding actor resources and infrastructures', 'articulating value proposition', 'engaging with other actors', and 'influencing explicit institutions'. The authors will discuss each below in relation to service ecosystems change and will formulate hypotheses in which these lowerorder capabilities mediate the effect of the higher-order capabilities 'visioning' and 'timing' on success in influencing service ecosystems.

Resource integration is central to structuration and re-structuration of service ecosystems (Vargo and Akaka, 2012; Koskela-Huotari et al., 2016). However, not all resource integration is the same from the perspective of service ecosystem change. Peters (2016) 
highlights the difference between homopathic and heteropathic resource integration. Homopathic resource integration is based on summative processes, where the effect of the integrated resources is identical to the sum of its parts. Heteropathic resource integration, on the other hand, is based on emergent processes and may lead to new properties on the service ecosystem level (Peters, 2016). Therefore, it is central for an actor aiming to influence service ecosystems to understand actors' resources and their possible homopathic or heteropathic properties. In addition to operant resources - resources capable of influencing other resources - ecosystem infrastructures constitute operand resources necessary for resource integration (Vargo and Lusch, 2004), and shaping the infrastructure is an acknowledged strategy for ecosystem change (Marquis and Raynard, 2015). Marquis and Raynard (2015) suggest that firms can influence ecosystems through social, technological, and physical infrastructures and by addressing socio-cultural issues which indirectly impact the ecosystem. However, change cannot be induced without understanding the state of the ecosystem. Hence, 'visioning' and 'timing' impact service ecosystems through the capability of 'understanding actor resources and infrastructures'. That is, if the actors wish to act upon their vision in a timely manner, they require insights into other actors' capabilities and operand resources residing in the service ecosystem. Consequently, it is suggested that:

H2a: 'Visioning' is positively related to the success in influencing the service ecosystem through 'understanding actor resources and infrastructures'.

H2b: 'Timing' is positively related to the success in influencing the service ecosystem through 'understanding actor resources and infrastructures'.

‘Articulating value proposition’ refers to the firm's capacity to define, communicate, and improve its value proposition to customers. Marketing and management research have agreed 
on the importance of value proposing (see Storbacka et al., 2016; Skålen et al., 2015), and, in service-dominant logic, value propositions have an established role in the foundational premises (Vargo and Lusch, 2004; 2008). Recent service-dominant logic literature emphasizes that value proposing enables resource integration and supports relationship formation, thus contributing to ecosystem wellbeing (Ballantyne et al., 2011; Frow et al., 2014). Well-crafted and actionable value propositions enable actors to participate in value cocreation (Skålen et al., 2015), since value propositions facilitate exchanges between ecosystem actors (Vargo and Lusch 2004; 2008; 2016). The relationship between value propositions and ecosystem change is also evident: as Frow et al. (2014) state, “the role of the value proposition within an ecosystem moves from the proposal of a resource offering between actors to shaping of resource integration between actors within the system” (p. 335). The basic, micro-level exchange takes place through value propositions, which become meso-level when extended to triads and macro-level when connected to networks (Chandler and Vargo, 2011). Hence, it can be argued that 'articulating value proposition' is a relevant dynamic capability linked to service ecosystem change. In a similar vein, Vargo and Akaka (2012) highlight “proposing value” as one of the key mechanisms involved in formation and re-formation of service ecosystems, and the impacts of 'timing' and 'visioning' are expected to be mediated by value propositions. Hence, it is proposed that:

H3a: 'Visioning' is positively related to the success in influencing the service ecosystem through 'articulating value proposition'.

H3b: 'Timing' is positively related to the success in influencing the ecosystem through 'articulating value proposition'. 
The systems perspective on service ecosystems highlights that a service ecosystem is a network of interacting actors (Lusch et al., 2010; Ng et al., 2012). Thus, a service ecosystem is changed if new actors join the network, existing actors leave the network, or the relationships between the actors are altered. However, no actor is likely to have a unilateral ability to influence the composition of their actor network or the types of relationships occurring. Thus, this paper proposes that focal actors influence their relationships and thus the overall network through subtler actor engagement: for example, an actor may not be able to start a new relationship onesidedly, but the actor can nevertheless engage with the other party. Building on extant research on customer engagement (cf., Brodie et al., 2011), Storbacka et al. (2016) conceptualize actor engagement as a microfoundation for value cocreation, and they suggest that actor engagement is a prerequisite for resource integration - and thus for value cocreation. This perspective is echoed by Taillard et al. (2016), who suggest that interactions between actors are necessary for shared intentions between actors to emerge, something which in turn is required for ecosystemlevel emergence. Hence, this paper hypothesizes that 'engaging with other actors' is a necessary capability for the focal actor to influence the service ecosystem. Thus, it is suggested that:

H4a: 'Visioning' is positively related to the success in influencing the service ecosystem through 'engaging with other actors'.

H4b: 'Timing' is positively related to the success in influencing the service ecosystem through 'engaging with other actors'.

The institutional work literature suggests that actors can alter institutions surrounding them (Lawrence and Suddaby, 2006). Thus, firms are both embedded in their institutional context (Chandler and Vargo, 2011; Siltaloppi et al., 2016) and able to recreate that context. In many cases, this duality has been investigated from the macro-level perspective and downwards rather 
than upwards from the micro-level: for example, Edvardsson et al. (2011) suggest that "studies could examine how changes in the macro-environment (such as new laws and regulations) affect service systems and actors” (p. 336). In accordance with this paper’s proactive approach, the present authors submit that it is equally important to understand how actors can induce change in institutions through their dynamic capabilities. This submission is aligned with the central tenets of service-dominant logic, which explicitly advocate the view that institutions and institutional arrangements are endogenously generated (Vargo and Lusch, 2016). Alvarez et al. (2015) highlight the role of actors in shaping institutions by "defining new institutional norms and regulations that govern the production, distribution, and consumption associated with these new opportunities” (p. 97). Accordingly, “actors work to influence their institutional contexts through such strategies as technical and market leadership, lobbying for regulatory change and discursive action” (Lawrence and Suddaby, 2006, p. 215). The existing studies show that institutional complexity inherent in service ecosystems is conducive to institutional work (Siltaloppi et al., 2016) and that interdependent breaking, making, and maintaining of institutions is also valid when innovating service ecosystems (Koskela-Huotari et al., 2016). Nevertheless, such work is preceded by 'visioning' and 'timing', which provide direction and understanding of when the work is beneficial. Hence, it is proposed that:

H5a: 'Visioning' is positively related to the success in influencing the service ecosystem through 'influencing explicit institutions’.

H5b: 'Timing' is positively related to the success in influencing the service ecosystem through 'influencing explicit institutions’.

Figure 1 summarizes the preliminary research model. 
Figure 1. Conceptual model: Dynamic capabilities associated with proactively influencing service ecosystems

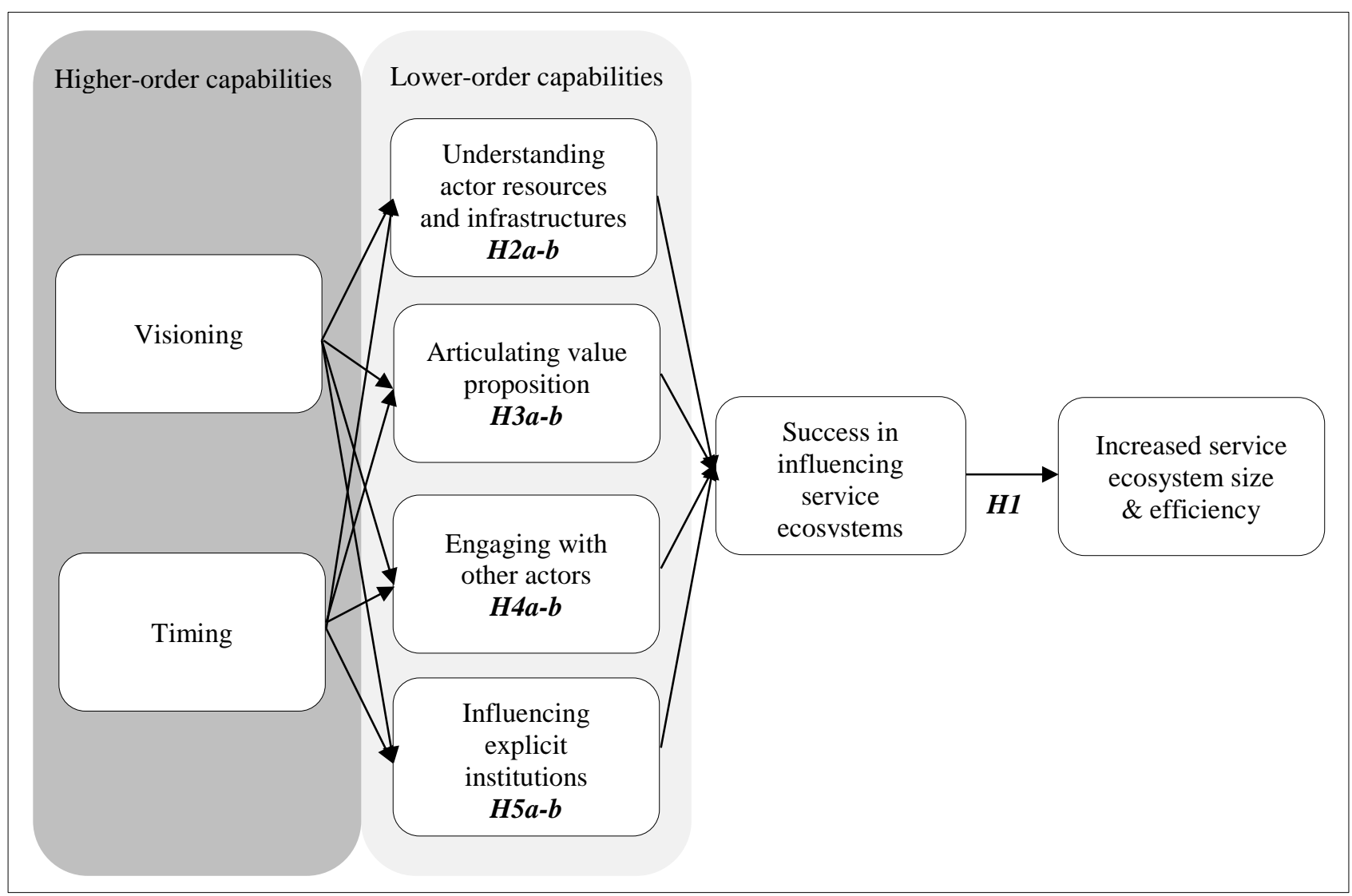

\section{Methodology}

The study was conducted with firms related to the primary sector, which comprises agriculture, forestry, fishing, mining, and quarrying (Ravallion and Datt, 1996). Such a context has been previously studied from the service-dominant logic perspective (cf., Liang, 2017), and yet there has been no explicit attempt to examine service ecosystems related to the primary sector. The main criterion for including firms in the sample was previous experience in influencing their service ecosystems - for example, creating a market for a completely new type of service by an agricultural firm in collaboration with its partners - that had been documented in publicly available sources such as annual reports or articles in popular business press. The sampling of individual respondents focused on roles typically associated with strategy development and deployment (e.g., founder, chief executive officer, business development manager, vice president of strategy and planning). All firms consented to take part in the study under the 
condition of full anonymity. Data collection took place in May 2015 through a self-administered online questionnaire sent to 178 owners and senior managers, generating 127 replies (response rate of 71 percent), resulting in the final set of 106 responses after elimination of incomplete answers. Due to the exploratory nature of the research, the items were developed specifically for this study based on the existing literature (see Appendix A). All items were assessed on a seven-point Likert scale (1 = “strongly disagree”, 7 = "strongly agree”).

An exploratory factor analysis with principal components analysis (oblique factor rotation) was conducted for construct purification. One major difference emerged during this process in comparison to the preliminary research model: the dynamic capability of 'engaging with other actors' was divided into two constructs - 'engaging with commercial actors' and 'engaging with non-commercial actors and understanding implicit institutions'. Hence, the dynamic capabilities are represented by seven constructs with three to five items each. In addition, two constructs measure success in influencing service ecosystems and increased service ecosystem size and efficiency. Descriptive statistics for each construct are presented in Table 1. Appendix A provides information on individual items and their factor loadings

\begin{tabular}{|c|c|c|c|c|c|c|c|c|c|c|c|c|c|c|}
\hline Construct & $\begin{array}{l}\text { Number } \\
\text { of items }\end{array}$ & Mean & SD & $\mathrm{CR}$ & AVE & 1. & 2. & 3. & 4. & 5. & 6. & 7. & 8. & 9. \\
\hline $\begin{array}{l}\text { 1. Articulating value } \\
\text { proposition (AVP) }\end{array}$ & 4 & 4.80 & 1.10 & 0.89 & 0.67 & 0.82 & & & & & & & & \\
\hline $\begin{array}{l}\text { 2. Engaging with } \\
\text { commercial actors }(E C A) \neq \\
\text { 3. Increased service } \\
\text { ecosystem size and }\end{array}$ & 3 & 5.50 & 0.91 & 0.86 & 0.68 & 0.36 & 0.82 & & & & & & & \\
\hline $\begin{array}{l}\text { efficiency (ISESE) } \\
\text { 4. Influencing explicit }\end{array}$ & 3 & 5.32 & 0.96 & 0.75 & 0.51 & 0.42 & 0.29 & 0.71 & & & & & & \\
\hline $\begin{array}{l}\text { institutions (IEI) } \\
\text { 5. Engaging with non- }\end{array}$ & 4 & 4.80 & 1.28 & 0.90 & 0.69 & 0.29 & 0.33 & 0.37 & 0.83 & & & & & \\
\hline $\begin{array}{l}\text { commercial actors and } \\
\text { understanding implicit } \\
\text { institutions (ENCAUII) } \pm \\
6 \text {. Success in influencing }\end{array}$ & 3 & 4.82 & 1.14 & 0.87 & 0.70 & 0.27 & 0.41 & 0.28 & 0.52 & 0.84 & & & & \\
\hline service ecosystems (SISE) & 2 & 5.52 & 1.10 & 0.89 & 0.80 & 0.39 & 0.23 & 0.36 & 0.58 & 0.36 & 0.89 & & & \\
\hline $\begin{array}{l}\text { 7. Timing } \\
\text { 8. Understanding actor } \\
\text { resources and infrastructures }\end{array}$ & 5 & 4.48 & 1.05 & 0.90 & 0.64 & 0.44 & 0.42 & 0.36 & 0.52 & 0.44 & 0.46 & 0.80 & & \\
\hline (UARI) & 3 & 4.69 & 1.18 & 0.89 & 0.73 & 0.46 & 0.41 & 0.37 & 0.31 & 0.40 & 0.24 & 0.57 & 0.86 & \\
\hline 9. Visioning & 5 & 4.66 & 1.13 & 0.90 & 0.65 & 0.59 & 0.34 & 0.47 & 0.39 & 0.52 & 0.48 & 0.61 & 0.61 & 0.81 \\
\hline $\begin{array}{l}\text { Notes: } \mathrm{CR} \text {, composite reliabi } \\
\text { significant at the } 0.05 \text { level (t }\end{array}$ & $\begin{array}{l}\text { AVE, av } \\
\text { tailed). }\end{array}$ & ge varia & xtracte & he squa & coot of & E appe & in ital & on the & onal of & orrelat: & natrix. & 11 corre & ions are & \\
\hline
\end{tabular}

In addition to the number of items per construct, Table 1 reports values for each construct's mean, standard deviation (SD), composite reliability (CR), average variance extracted (AVE) 
and its square root, as well as correlations between constructs. Due to the data collection method being restricted to a single data collection point, Harman's one-factor test (Podsakoff and Organ, 1986) was employed to assess common method variance, but no major issues were discovered.

Partial least squares structural equation modeling (PLS-SEM) was used to test the relationships between the constructs because: (1) it is suitable for exploratory studies; (2) no assumptions regarding the normal distribution of data are required; and (3) high levels of statistical power are achieved for complex models even when the sample size is relatively small, as in the present study (Hair et al., 2014). The mediating effects were assessed following Zhao et al.'s (2010) guidelines for PLS-SEM analysis, as recommended by Hair et al. (2017). Since the PLS model in the present study contains more than one mediator, the study relied upon the extension of these guidelines for multiple mediation analysis in PLS-SEM (Hair et al., 2017). As a result, all relationships were tested simultaneously within a single PLS model.

SmartPLS 3.2.6 software (Ringle et al., 2015) was used in the analysis. For the bootstrapping procedure that allows testing of the significance of path coefficients, the recommended 5000 bootstrap samples (Hair et al., 2017) were employed.

\section{Results}

The measurement and structural models were evaluated based on the guidelines from Hair et al. (2014; 2017). All indicators in the PLS model were specified as reflective following “classical test theory” (Hair et al., 2017). Indicator reliability was achieved, since outer loadings of all indicators are higher than 0.70 , with the exception of the item "The size of our market(s) has increased during the recent years” (outer loading 0.54). The composite reliability values are above 0.75 for all constructs (reported in Table 1), which means that internal consistency reliability is also achieved. 
The AVE (average variance extracted) values for all constructs exceed 0.50 (see Table 1), which suggests sufficient levels of convergent validity. Discriminant validity is achieved, since: (1) outer loadings of all indicators are higher on their respective constructs than all crossloadings with other constructs; (2) following the Fornell-Larcker criterion, the square root of each construct's AVE is higher than any correlation with other constructs; and (3) following the HTMT (Heterotrait-Monotrait Ratio) criterion, the HTMT values for all pairs of constructs are well below the 0.85 threshold, and their respective confidence intervals do not include the value 1. VIF (variance inflation factor) values for all predictor constructs are higher than 0.20 and lower than 5, suggesting that there are no collinearity issues with the model. The results of hypothesis testing are reported in Table 2, which contains the path coefficients $\beta$ together with corresponding $t$-values.

Table 2. Results: Direct and indirect effects

\begin{tabular}{|c|c|c|c|}
\hline $\begin{array}{l}\text { Structural path } \\
\end{array}$ & $\beta$ & $t$-value & Result of hypothesis testing \\
\hline \multicolumn{4}{|l|}{ Direct effects } \\
\hline Visioning $\rightarrow$ UARI & 0.41 & $4.29 * * *$ & \\
\hline Visioning $\rightarrow$ AVP & 0.50 & $4.93 * * *$ & \\
\hline Visioning $\rightarrow$ ECA $\ddagger$ & 0.14 & 1.25 & \\
\hline Visioning $\rightarrow$ ENCAUII¥ & 0.40 & $3.53 * * *$ & \\
\hline Visioning $\rightarrow$ IEI & 0.12 & 1.07 & \\
\hline Timing $\rightarrow$ UARI & 0.32 & $2.94 * * *$ & \\
\hline Timing $\rightarrow$ AVP & 0.14 & 1.32 & \\
\hline Timing $\rightarrow$ ECA & 0.34 & $2.28 * *$ & \\
\hline Timing $\rightarrow$ ENCAUII & 0.19 & 1.59 & \\
\hline Timing $\rightarrow$ IEI & 0.44 & $3.86 * * *$ & \\
\hline $\mathrm{UARI} \rightarrow \mathrm{SISE}$ & -0.17 & 1.54 & \\
\hline $\mathrm{AVP} \rightarrow \mathrm{SISE}$ & 0.14 & 1.36 & \\
\hline ECA $\rightarrow$ SISE & -0.04 & 0.32 & \\
\hline ENCAUII $\rightarrow$ SISE & -0.02 & 0.24 & \\
\hline IEI $\rightarrow$ SISE & 0.44 & $3.95 * * *$ & \\
\hline Visioning $\rightarrow$ SISE & 0.29 & $2.42 * *$ & \\
\hline Timing $\rightarrow$ SISE & 0.11 & 0.98 & \\
\hline $\mathrm{SISE} \rightarrow \mathrm{ISESE}$ & 0.36 & $3.98 * * *$ & H1: Supported \\
\hline \multicolumn{4}{|l|}{ Indirect effects } \\
\hline Visioning $\rightarrow$ UARI $\rightarrow$ SISE & -0.07 & 1.40 & H2a: Not supported \\
\hline Timing $\rightarrow$ UARI $\rightarrow$ SISE & -0.06 & 1.31 & H2b: Not supported \\
\hline Visioning $\rightarrow$ AVP $\rightarrow$ SISE & 0.07 & 1.25 & H3a: Not supported \\
\hline Timing $\rightarrow$ AVP $\rightarrow$ SISE & 0.02 & 0.85 & H3b: Not supported \\
\hline Visioning $\rightarrow$ ECA $¥ \rightarrow$ SISE & -0.01 & 0.23 & H4a: Not supported \\
\hline Timing $\rightarrow$ ECA $\rightarrow$ SISE & 0.01 & 0.28 & H4b: Not supported \\
\hline Visioning $\rightarrow$ ENCAUII $\rightarrow$ SISE & -0.01 & 0.23 & H4a: Not supported \\
\hline Timing $\rightarrow$ ENCAUII $\rightarrow$ SISE & 0.00 & 0.19 & H4b: Not supported \\
\hline
\end{tabular}




\begin{tabular}{|c|c|c|c|}
\hline Visioning $\rightarrow$ IEI $\rightarrow$ SISE & 0.05 & 1.11 & H5a: Not supported \\
\hline Timing $\rightarrow$ IEI $\rightarrow$ SISE & 0.20 & $2.62 * * *$ & H5b: Supported \\
\hline \multicolumn{4}{|c|}{$\begin{array}{l}\text { Notes: }{ }^{* *} \mathrm{p}<0.05 ; * * * \mathrm{p}<0.01 \text {; two-tailed tests of significance; } \\
\text { ₹ after the factor analysis, the hypothesized construct 'engaging with other actors' was separated into } \\
\text { 'engaging with commercial actors' (ECA) and 'engaging with non-commercial actors and understanding } \\
\text { implicit institutions' (ENCAUII). }\end{array}$} \\
\hline
\end{tabular}

As Table 2 demonstrates, 'success in influencing service ecosystems' positively influences ‘increased service ecosystem size and efficiency’ $(\beta=0.36, p<0.01)$, supporting H1. It was hypothesized that the lower-order capabilities would mediate the effect of the higher-order capabilities 'visioning' and 'timing' on 'success in influencing service ecosystems'. However, the study discovered that only one lower-order capability, 'influencing explicit institutions', acts as a mediator for a single relationship - the effect of 'timing' on 'success in influencing service ecosystems' $(\beta=0.20, p<0.01)$. Since the direct relationship between 'timing' and 'success in influencing service ecosystems' is not significant, one can conclude that this mediating effect represents indirect-only or full mediation (Zhao et al., 2010; Hair et al., 2017). Thus, of hypotheses H2-H5, support was found only for H5b. Contrary to the hypotheses and the theories behind them, higher-order capability 'visioning' has a direct positive effect only on 'success in influencing service ecosystems' $(\beta=0.29, p<0.05)$.

In addition, five significant relationships emerged between higher-order and lowerorder capabilities that had not been hypothesized separately. 'Visioning' has direct positive effects on 'understanding actor resources and infrastructures' $(\beta=0.41, p<0.01)$, 'articulating value proposition' ( $\beta=0.50, p<0.01$ ), and 'engaging with non-commercial actors and understanding implicit institutions' $(\beta=0.40, p<0.01)$; whereas 'timing' directly and positively influences 'understanding actor resources and infrastructures' $(\beta=0.32, p<0.01)$ and 'engaging with commercial actors' $(\beta=0.34, p<0.05)$. Finally, it emerged that four out of five lower-order capabilities do not have any influence on 'success in influencing service ecosystems'. In contrast, 'influencing explicit institutions' has a strong positive effect on success in influencing service ecosystems $(\beta=0.44, p<0.01)$. 
Figure 2 visualizes the results of the exploratory study by showing the significant path coefficients, together with the $\mathrm{R}^{2}$ values (coefficients of determination) of the endogenous constructs.

Figure 2. Structural model results

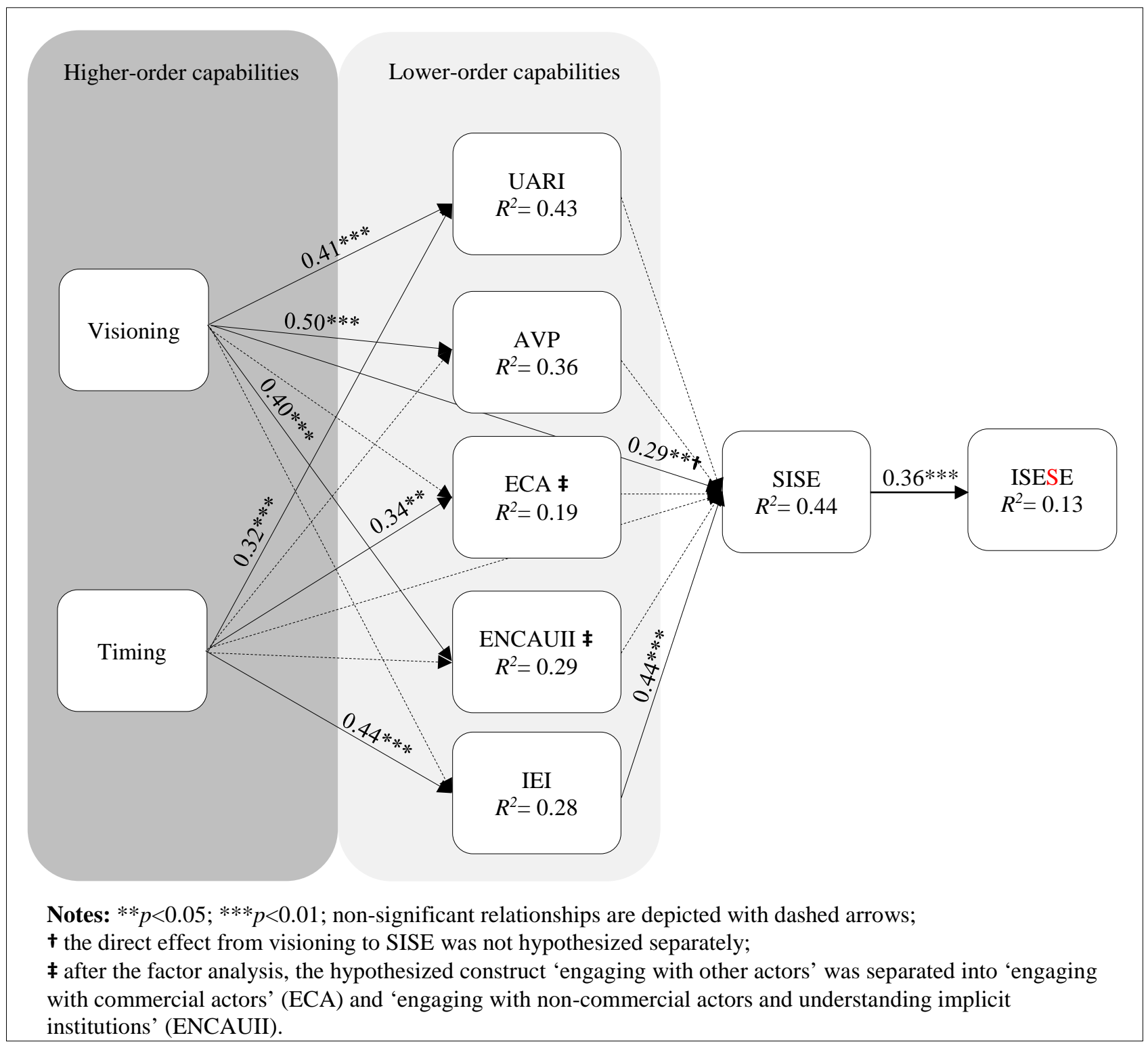


As Figure 2 demonstrates, $\mathrm{R}^{2}$ values for the endogenous latent variables do not exceed 0.44 , supporting the conclusion that the model's predictive power is moderate. $\mathrm{Q}^{2}$ values were calculated to assess the predictive relevance of the model. All $\mathrm{Q}^{2}$ values are above zero, suggesting that the exogenous constructs have predictive relevance for the endogenous constructs (Hair et al., 2014).

\section{Conclusions}

Theoretical contribution

Inspired by the service-dominant logic and management literature, this paper proposed that dynamic capabilities can be seen as a special case of operant resources, which actors employ to conduct institutional work and thus to ultimately influence service ecosystems. Even though service-dominant logic acknowledges that actors can influence how service ecosystems evolve by affecting the underlying institutions, and has called for more research on the topic (Chandler and Lusch, 2015), empirical studies on the dynamics of actor influence on service ecosystems are scarce.

The present exploratory research studied which actor-level dynamic capabilities are associated with successfully influencing service ecosystems. By showing that actors can shape ecosystems through specific higher- and lower-order dynamic capabilities, the findings extend Koskela-Huotari et al. (2016), who showed that actors can shape ecosystems by breaking, maintaining, and enhancing the institutionalized rules of resource integration on micro, meso and macro levels of the service ecosystem. Furthermore, this study answers the call for more research on the relationship between higher- and lower-order capabilities (Peteraf et al., 2013), and shows that not all lower-order dynamic capabilities necessarily relate to ecosystem change, although they might influence actor's competitiveness or strategic benefit.

The findings of the study contribute to both the service-dominant logic and the dynamic capabilities literatures. First, the research builds on the existing service-dominant logic research by conceptualizing dynamic capabilities as a special case of operant resources (Madhavaram 
and Hunt, 2008; Karpen et al., 2015) and suggesting that actors are able to use these dynamic capabilities to influence service ecosystems. Dynamic capabilities, therefore, enable actors to conduct institutional work. This conceptualization - dynamic capabilities as operant resources with the capacity to influence service ecosystems - is both deeply rooted in service-dominant logic research and compatible with its core lexicon. This contribution responds to Wilden et al.'s (2017) call for future research integrating service-dominant logic and the dynamic capabilities view in order to develop a more strategic approach to service-dominant logic.

Second, both of the higher-order capabilities identified - 'visioning' and 'timing' positively influenced the actors' success in influencing the service ecosystem, the former directly and the latter via the ability to influence explicit institutions. This dual finding is aligned with the most recent advances in the dynamic capabilities literature, which suggest that actors who are strategically predisposed to proactively changing the service ecosystem require different dynamic capabilities than the more reactively-inclined sensing and seizing capabilities (Wilden et al., 2016). Even though most of the dynamic capabilities literature has focused on sensing pre-existing opportunities, some authors have acknowledged the importance of proactive and creative visioning (e.g., Zahra et al., 2006; Wang and Ahmed, 2007). In a similar vein, the importance of time and timing has been noted by several prominent dynamic capability scholars (cf., Eisenhardt and Martin, 2000; Teece, 2007; Zott, 2003). The present findings suggest that 'timing' should be elevated from an extraneous variable to a key dynamic capability. On the other hand, the identified higher-order capabilities suggest that servicedominant logic should direct more attention to concepts such as 'vision', 'visioning', 'time', and 'timing', which until now have been rarely discussed in the extant literature barring some individual exceptions (cf., Ojasalo et al., 2015).

Third, the research identified five lower-order capabilities and investigated their role as mediators between the two higher-order capabilities and success in influencing service ecosystems. Surprisingly, only one of the lower-order capabilities - 'influencing explicit 
institutions' - had a direct effect on the success in influencing the service ecosystem, and acted as a mediator for 'timing', whereas all the other lower-order capabilities - 'understanding actor resources and infrastructures', ‘articulating value proposition', 'engaging with commercial actors' and 'engaging with non-commercial actors and understanding implicit institutions' did not demonstrate direct effects, nor did they act as mediators. From the dynamic capabilities literature perspective, this finding questions Schilke’s (2014) suggestion that higher-order capabilities always demonstrate their impact via lower-order capabilities. For the servicedominant logic literature, this finding poses several implications. It suggests that many of the central constructs of service-dominant logic such as value propositions, resources, and relationships are not sufficient by themselves - even together - to explain how actors can influence service ecosystems. It may be that these lower-order dynamic capabilities relate to the micro-level dyadic exchanges rather than to service ecosystem change, and hence they might be more closely related to actor-level success factors such as profitability or sales. This calls into question to what extent ecosystem change is driven by understanding the market players and the infrastructure as reflected by engaging with commercial and non-commercial partners, and whether these capabilities are merely hygiene factors (necessary but not sufficient). It may also be that the mechanics through which dynamic capabilities influence ecosystem change are far more complicated than was tested for in the present study. For example, the effect of the dynamic capabilities of engaging with commercial and noncommercial actors may become visible in the long term, which requires a longitudinal research approach. Furthermore, it might be that the construct 'articulating value proposition' was restrictive in that it concentrated on the capability to communicate rather than the capability to radically change value propositions, which may undermine the importance of value proposing in general, and should be taken into account when interpreting the present results.

Fourth, the findings confirm the link between actors' ability to influence explicit institutions and service ecosystem change. In particular, the findings of the present study 
corroborate the suggestion by Vargo et al. (2016) that service ecosystem change does not automatically occur when actors introduce new value propositions; system-level change takes place only after the resulting new practices become institutionalized. However, new constructs are needed to further illuminate the lower-order capability of 'influencing explicit institutions'. Of particular promise are 'terminology', 'representations', 'regulations' and 'norms', introduced to the service-dominant logic discourse in the early 2010s (Vargo, 2010; Vargo and Lusch, 2011) from the markets-as-practices approach (Kjellberg and Helgesson, 2006; 2007).

Finally, the findings suggest a strong link between actors' ability to influence service ecosystems and the increased service ecosystem size and efficiency. This result is very well aligned with service-dominant logic's notions of reciprocal and interconnected value creation, as innovating service ecosystems should result in more value for all actors involved. However, this recorded relationship between the ability to influence service ecosystems and the increase in ecosystem size and efficiency could also potentially work in the other direction, suggesting that actors are only able to influence service ecosystems if their vision for the future ecosystem holds promise of increased value cocreation opportunities for all (or several) actors. For the dynamic capabilities literature, on the other hand, this result suggests a novel and more systemic dependent variable: at the moment, the vast majority of the dynamic capabilities research has focused on investigating the relationship between dynamic capabilities and firm performance (Wang and Ahmed, 2007), leaving lesser attention to be paid to meso-level implications such as market size or value creation to other actors.

\section{Managerial implications}

Appreciating that the firm is not external to its "market” but embedded in its service ecosystem opens novel strategic options for managers. In addition to reactively positioning and competing at the marketplace, firms can choose to proactively influence their service ecosystems for increased size and efficiency. Hence, it is suggested that managers can broaden their scope from 
maximizing direct firm results towards creating an advantageous environment by actively influencing the political and judicial systems as well as cultural norms in their favor.

The findings suggest that firms seeking to influence their service ecosystems cannot rely on merely introducing new product or services - even if these new products or services offer dramatically improved value for the customers. Instead, firms aiming to influence service ecosystems should have a clear and compelling vision of how they would like to see their ecosystem developing. Additionally, such ecosystem-shaping firms should possess welldeveloped capabilities to influence terminology and regulations. Lobbying to alter restrictive regulations is a familiar part of the corporate strategic repertoire, but the possibility of introducing and altering names, terms, concepts or phrases is often overlooked in strategy work.

Furthermore, the findings show that managers should consider collaborating with other parties when influencing explicit institutions. For example, the findings suggest that being the organization that media and government officials turn to for advice or comments made it possible for the focal firm to successfully influence its institutional context. This highlights the importance of fostering relationships with media and government on multiple organizational levels, from top management to functional experts, to establish a key role for the firm within its service ecosystem.

Finally, firms are able to augment their ability to influence service ecosystems’ explicit institutions by having a good understanding of the development speed of their ecosystem and timing their actions accordingly.

\section{Limitations and future research}

The present research deliberately took the perspective of a focal actor, and the study was conducted among commercial firms. These limitations should be kept in mind when assessing the findings. However, there are no reasons to believe that the identified dynamic capabilities for influencing service ecosystems - timing, visioning, and influencing explicit institutions - 
would not be applicable to other types of actors as well. In fact, other types of actors such as policy-makers and special interest groups might be better positioned to influence explicit institutions than commercial firms. Thus, it is hoped that the identified dynamic capabilities for service ecosystem change provide a starting point for further research from the perspective of other actors, and thus a platform for developing a truly actor-to-actor view on service ecosystem change.

An additional limitation of this study is its focus on the positive outcomes of actorspecific dynamic capabilities. Due to ecosystem complexity, other, unintended outcomes might come about, or externalities might change the ecosystem beyond the control of the focal actor. Hence, different types of ecosystem changes might need to be identified, and control variables (e.g., power relations) might also need to be added. In addition, it might well be that some dynamic capabilities - or indeed lack thereof - might have negative consequences, such as unintended changes in relationships (exit, entrance or compilations of actors) or modifications in infrastructures.

Regarding the methodology of the paper, this study is limited to firms with previous experience in influencing their service ecosystems within the primary sector (already noted to comprise agriculture, forestry, fishing, mining, and quarrying). Future studies in other contexts and among actors other than commercial firms (e.g., special interest groups, public actors) are needed. Another limitation concerns the sample size: while it is not problematic per se due to the exploratory nature of the study and particular suitability of PLS-SEM for analyzing datasets of similar size and complexity (Hair et al., 2017), testing the model on a larger sample would improve the generalizability of the results. In addition, the study cannot be considered longitudinal since data collection occurred at a single point in time - a fact which can be seen as a further limitation, albeit typical within the exploratory setting.

Also, the study design did not make it possible to study the respondent characteristics (e.g., age or profession) or enable the comparison of different actors or departments (e.g., 
marketing, manufacturing, accounting) within or across the firms. Hence, it is suggested that future studies could examine the deployment of dynamic capabilities within and across firms to understand the ecosystem change more in-depth.

Finally, all variables used in this study are subjective; however, business scholars have consistently found that such measures lead to results that are not significantly different from those relying on so-called objective variables, as can be seen for instance in Dawes (1999), Wall et al. (2004), Singh et al. (2016), and Vij and Bedi (2016).

In terms of further research, the authors acknowledge that previous work on dynamic capabilities concentrated on explaining firm performance rather than ecosystem change (Wang and Ahmed, 2007), whereas the present study focused on actors' ability to drive change in service ecosystems. Hence, it is suggested that future research would study the relationship between firm performance and service ecosystem change.

The present research conceptualized dynamic capabilities as a special case of operant resources underlying the institutional work done by actors to influence the service ecosystems surrounding them. However, this study was exploratory in nature and identified only three dynamic capabilities with significant effect on success in influencing service ecosystems. Thus, the authors encourage future research on dynamic capabilities in the context of service ecosystem change. For example, influencing generally accepted social norms or industry conventions, influencing symbols legitimizing service ecosystems (such as industry/trade associations, events and awards), or renegotiating actors’ roles in the service ecosystem may prove to be dynamic capabilities linked to institutional work. In particular, a longitudinal research approach might prove useful in outlining the interrelationships between institutional work, dynamic capabilities, and the service ecosystem’s development, and eventual differences in the importance of particular dynamic capabilities for various types of ecosystems or an ecosystem’s development trajectories (e.g., emerging vs. mature markets). 
Future research should also examine the notion of dynamic bundles, i.e., combinations of resources and capabilities (Peteraf et al., 2013, p. 1405), as resources and non-dynamic (ordinary) capabilities were delimited from this exploratory study. Nevertheless, an increased understanding of such dynamic bundles in which dynamic capabilities and ordinary capabilities interact in resource integration and value creation could considerably advance service-dominant logic theorizing.

The authors also encourage further research on how the identified dynamic capabilities to influence service ecosystems are applied in practice. Merely knowing that capabilities related to visioning, timing, and influencing explicit institutions are needed illuminates only a fraction of the big picture - more detailed understanding is needed on how such capabilities are developed and used. Effectuation logic (Sarasvathy, 2001; 2009) and configuration (Miller and Friesen, 1984; Miller, 1987) theories could be particularly fruitful theoretical lenses to develop such an understanding.

Finally, as Kjellberg and Helgesson (2006; 2007) suggest, service ecosystems stem from multiple and overlapping market practices, whereas this study deliberately took the perspective of one focal actor and its dynamic capabilities for inducing service ecosystem change. Considering the interdependent nature of actors, this paper encourages future studies on the multiple actors' collective efforts to influence service ecosystems, and the role of dynamic capabilities in this interplay. 


\section{References}

Aal, K., Di Pietro, L., Edvardsson, B., Renzi, M.F. and Guglielmetti Mugion, R. (2016), "Innovation in service ecosystems: an empirical study of the integration of values, brands, service systems and experience rooms”, Journal of Service Management, Vol. 27 No. 4, pp. 619-651.

Agarwal, R. and Selen, W. (2009), “Dynamic capability building in service value networks for achieving service innovation”, Decision Sciences, Vol. 40 No. 3, pp. 431-475.

Akaka, M.A., \& Vargo, S.L. (2014), “Technology as an operant resource in service (eco) systems”, Information Systems and e-Business Management, Vol. 12 No. 3, pp. 367-384.

Akaka, M.A. and Vargo, S.L. (2015), “Extending the context of service: from encounters to ecosystems”, Journal of Services Marketing, Vol. 29 No. 6/7, pp. 453-462.

Alvarez, S.A., Young, S.L. and Woolley, J.L. (2015), “Opportunities and institutions: A cocreation story of the king crab industry”, Journal of Business Venturing, Vol. 30 No. 1, pp. 95-112.

Baker, W.E. and Sinkula, J.M. (1999), “The synergistic effect of market orientation and learning orientation on organizational performance”, Journal of the Academy of Marketing Science, Vol. 27 No. 4, pp. 411-427.

Ballantyne, D., Frow, P., Varey, R.J. and Payne, A. (2011), “Value propositions as communication practice: taking a wider view”, Industrial Marketing Management, Vol. 40 No. 2, pp. 202-210.

Barney, J. (1991), “Firm resources and sustained competitive advantage”, Journal of Management, Vol. 17 No. 1, pp. 99-120.

Barreto, I. (2010), “Dynamic capabilities: a review of past research and an agenda for the future”, Journal of Management, Vol. 36 No. 1, pp. 256-280.

Battilana, J. and D’aunno, T. (2009), “Institutional work and the paradox of embedded agency”, in Lawrence, T.B, Suddaby, R. and Leca, B. (Eds.), Institutional work: Actors 
and agency in institutional studies of organizations, Cambridge University Press, Cambridge, UK, pp. 31-58.

Battilana, J., Leca, B. and Boxenbaum, E. (2009), “How actors change institutions: towards a theory of institutional entrepreneurship”, The Academy of Management Annals, Vol. 3 No. 1, pp. 65-107.

Bharadwaj, S., Clark, T. and Kulviwat, S. (2005), “Marketing, market growth, and endogenous growth theory: an inquiry into the causes of market growth", Journal of the Academy of Marketing Science, Vol. 33 No. 3, pp. 347-359.

Brodie, R.J., Hollebeek, L.D., Jurić, B. and Ilić, A. (2011), “Customer engagement: conceptual domain, fundamental propositions, and implications for research”, Journal of Service Research, Vol. 14 No. 3, pp. 252-271.

Burr, T. (2013), “Market cycles: bicycles, riders, industries, and environments in France and the United States, 1865-1914”, American Journal of Economics and Sociology, Vol. 72 No. 2, pp. 468-496.

Chandler, J.D. and Chen, S. (2016), "Practice styles and service systems”, Journal of Service Management, Vol. 27 No. 5, pp. 798-830.

Chandler, J.D. and Lusch, R.F. (2015), “Service systems: a broadened framework and research agenda on value propositions, engagement, and service experience”, Journal of Service Research, Vol. 18 No. 1, pp. 6-22.

Chandler, J.D. and Vargo, S.L. (2011), “Contextualization and value-in-context: how context frames exchange”, Marketing Theory, Vol. 11 No. 1, pp. 35-49.

Cochoy, F. (2009), “Driving a shopping cart from STS to business, and the other way round: on the introduction of shopping carts in American grocery stores (1936-1959)”, Organization, Vol. 16 No. 1, pp. 31-55.

Collis, D.J. (1994), “Research note: how valuable are organizational capabilities?”, Strategic Management Journal, Vol. 15, pp. 143-152. 
Dawes, J. (1999), “The relationship between subjective and objective company performance measures in market orientation research: further empirical evidence”, Marketing Bulletin, Vol. 10, pp. 65-75.

Day, G.S. (1994), “The capabilities of market-driven organizations”, Journal of Marketing, Vol. 58 No. 4, pp. 37-52.

Day, G.S. (2011), “Closing the marketing capabilities gap”, Journal of Marketing, Vol. 75 No. 4, pp. 183-195.

den Hertog, P., van der Aa, W. and de Jong, M.W. (2010), “Capabilities for managing service innovation: towards a conceptual framework”, Journal of Service Management, Vol. 21 No. 4, pp. 490-514.

Edvardsson, B., Tronvoll, B. and Gruber, T. (2011), “Expanding understanding of service exchange and value co-creation: a social construction approach”, Journal of the Academy of Marketing Science, Vol. 39 No. 2, pp. 327-339.

Eisenhardt, K.M. and Martin, J.A. (2000), “Dynamic capabilities: what are they?”, Strategic Management Journal, Vol. 21 No. 10-11, pp. 1105-1121.

Frow, P., McColl-Kennedy, J.R., Hilton, T., Davidson, A., Payne, A. and Brozovic, D. (2014), "Value propositions: a service ecosystems perspective”, Marketing Theory, Vol. 14 No. 3, pp. 327-351.

Garud, R., Hardy, C. and Maguire, S. (2007), “Institutional entrepreneurship as embedded agency: an introduction to the Special Issue”, Organization Studies, Vol. 28 No. 7, pp. 957-969.

Giddens, A. (1984), The Constitution of Society: Outline of the Theory of Structuration, University of California Press, Berkeley, CA.

Granqvist, N., Grodal, S. and Woolley, J.L. (2013), “Hedging your bets: explaining executives’ market labeling strategies in nanotechnology”, Organization Science, Vol. 24 No. 2, pp. 395-413. 
Greenwood, R. and Suddaby, R. (2006), “Institutional entrepreneurship in mature fields: the big five accounting firms”, Academy of Management Journal, Vol. 49 No. 1, pp. 27-48. Hair, J.F., Hult, G.T.M., Ringle, C.M. and Sarstedt, M. (2014), A Primer on Partial Least Squares Structural Equation Modeling (PLS-SEM), 1st ed., Sage, Thousand Oaks, CA. Hair, J.F., Hult, G.T.M., Ringle, C.M. and Sarstedt, M. (2017), A Primer on Partial Least Squares Structural Equation Modeling (PLS-SEM), 2nd ed., Sage, Thousand Oaks, CA. Hills, S.B. and Sarin, S. (2003), "From market driven to market driving: an alternate paradigm for marketing in high technology industries”, Journal of Marketing Theory and Practice, Vol. 11 No. 3, pp. 13-24.

Hine, D., Parker, R., Pregelj, L. and Verreynne, M.-L. (2014), “Deconstructing and reconstructing the capability hierarchy”, Industrial and Corporate Change, Vol. 23 No. 5, pp. 1299-1325.

Humphreys, A. (2010), “Megamarketing: the creation of markets as a social process”, Journal of Marketing, Vol. 74 No. 2, pp. 1-19.

Jaworski, B., Kohli, A.K. and Sahay, A. (2000), “Market-driven versus driving markets”, Journal of the Academy of Marketing Science, Vol. 28 No. 1, pp. 45-54.

Karpen, I.O., Bove, L.L., Lukas, B.A. and Zyphur, M.J. (2015), “Service-dominant orientation: measurement and impact on performance outcomes”, Journal of Retailing, Vol. 91 No. 1, pp. 89-108.

Kjellberg, H. and Helgesson, C.-F. (2006), “Multiple versions of markets: multiplicity and performativity in market practice”, Industrial Marketing Management, Vol. 35 No. 7, pp. 839-855.

Kjellberg, H. and Helgesson, C.-F. (2007), “On the nature of markets and their practices”, Marketing Theory, Vol. 7 No. 2, pp. 137-162. 
Kjellberg, H., Nenonen, S. and Thomé, K.M. (forthcoming), “Analyzing service processes at the micro level: actors and practices”, the SAGE Handbook of Service-Dominant Logic, Sage, London, UK.

Koskela-Huotari, K., Edvardsson, B., Jonas, J.M., Sörhammar, D. and Witell, L. (2016), “Innovation in service ecosystems—breaking, making, and maintaining institutionalized rules of resource integration”, Journal of Business Research, Vol. 69 No. 8, pp. 29642971.

Kumar, N., Scheer, L. and Kotler, P. (2000), “From market driven to market driving”, European Management Journal, Vol. 18 No. 2, pp. 129-142.

Lawrence, T.B. and Suddaby, R. (2006), “Institutions and institutional work”, in Clegg, S.R., Hardy, C., Lawrence, T.B. and Nord, W.R. (Eds.), The SAGE Handbook of Organization Studies, 2nd ed., Sage, London, UK, pp. 215-254.

Liang, A.R.-D. (2017), “Considering the role of agritourism co-creation from a servicedominant logic perspective”, Tourism Management, Vol. 61, pp. 354-367.

Lusch, R.F. (2011), “Reframing supply chain management: a service-dominant logic perspective”, Journal of Supply Chain Management, Vol. 47 No. 1, pp. 14-18.

Lusch, R.F. and Vargo, S.L. (2014), Service-Dominant Logic: Premises, Perspectives, Possibilities, Cambridge University Press, Cambridge, UK.

Lusch, R.F., Vargo, S.L. and Gustafsson, A. (2016), “Fostering a trans-disciplinary perspectives of service ecosystems”, Journal of Business Research, Vol. 69 No. 8, pp. 2957-2963.

Lusch, R.F., Vargo, S.L. and Tanniru, M. (2010), “Service, value networks and learning”, Journal of the Academy of Marketing Science, Vol. 38 No. 1, pp. 19-31.

Madhavaram, S. and Hunt, S.D. (2008), “The service-dominant logic and a hierarchy of operant resources: developing masterful operant resources and implications for 
marketing strategy”, Journal of the Academy of Marketing Science, Vol. 36 No. 1, pp. 67-82.

Maglio, P.P., Vargo, S.L., Caswell, N. and Spohrer, J. (2009), “The service system is the basic abstraction of service science”, Information Systems and E-Business Management, Vol. 7 No. 4, pp. 395-406.

Mars, M.M., Bronstein, J.L. and Lusch, R.F. (2012), “The value of a metaphor: organizations and ecosystems”, Organizational Dynamics, Vol. 41 No. 4, pp. 271-280.

Marquis, C. and Raynard, M. (2015). “Institutional strategies in emerging markets”, The Academy of Management Annals, Vol. 9 No. 1 , pp. 291-335.

Menguc, B. and Auh, S. (2006), “Creating a firm-level dynamic capability through capitalizing on market orientation and innovativeness”, Journal of the Academy of Marketing Science, Vol. 34 No. 1, pp. 63-73.

Meynhardt, T., Chandler, J.D. and Strathoff, P. (2016), “Systemic principles of value cocreation: synergetics of value and service ecosystems”, Journal of Business Research, Vol. 69 No. 8, pp. 2981-2989.

Miller, D. (1987), “The genesis of configuration”, The Academy of Management Review, Vol. 12 No. 4, pp. 686-701.

Miller, D. and Friesen, P. (1984), “A longitudinal study of the corporate life cycle”, Management Science, Vol. 30 No. 10, pp. 1161-1183.

Narver, J.C. and Slater, S.F. (1990), “The effect of a market orientation on business profitability”, Journal of Marketing, Vol. 54 No. 4, pp. 20-35.

Ng, I., Badinelli, R., Polese, F., Nauta, P.D., Löbler, H. and Halliday, S. (2012), “SD logic research directions and opportunities: the perspective of systems, complexity and engineering”, Marketing Theory, Vol. 12 No. 2, pp. 213-217. 
Ng, I.C.L., Maull, R.S. and Smith, L. (2011), "Embedding the new discipline of service science”, in Demirkan, H., Spohrer, J.C. and Krishna, V. (Eds.), The Science of Service Systems, Springer, New York, NY, pp.13-35.

Ojasalo, K., Koskelo, M. and Nousiainen, A.K. (2015), “Foresight and service design boosting dynamic capabilities in service innovation”, in Agarwal, R., Selen, W., Roos, G. and Green, R. (Eds.), The Handbook of Service Innovation, Springer, London, UK, pp. 193-212.

Ordanini, A. and Parasuraman, A. (2011), "Service innovation viewed through a servicedominant logic lens: a conceptual framework and empirical analysis”, Journal of Service Research, Vol. 14 No. 1, pp. 3-23.

Palmer, M., Simmons, G., Robinson, P.R. and Fearne, A. (2015), “Institutional maintenance work and power preservation in business exchanges: Insights into industrial supplier workshops”, Industrial Marketing Management, Vol. 48, pp. 214-225.

Pavlou, P.A. and El Sawy, O.A. (2011), “Understanding the elusive black box of dynamic capabilities”, Decision Sciences, Vol. 42 No. 1, pp. 239-273.

Peteraf, M., Di Stefano, G. and Verona, G. (2013), “The elephant in the room of dynamic capabilities: bringing two diverging conversations together”, Strategic Management Journal, Vol. 34 No. 12, pp. 1389-1410.

Peters, L.D. (2016), “Heteropathic versus homopathic resource integration and value cocreation in service ecosystems”, Journal of Business Research, Vol. 69 No. 8, pp. 29993007.

Peters, L.D. (forthcoming), "Resource integration: concepts and processes”, the SAGE Handbook of Service-Dominant Logic, Sage, London, UK.

Pitelis, C.N. and Teece, D.J. (2010), “Cross-border market co-creation, dynamic capabilities and the entrepreneurial theory of the multinational enterprise”, Industrial and Corporate Change, Vol. 19 No. 4, pp. 1247-1270. 
Podsakoff, P.M. and Organ, D. (1986), “Self-reports in organizational research: problems and prospects”, Journal of Management, Vol. 12 No. 4, pp. 531-544.

Priem, R. and Butler, J. (2001) "Is the resource-based "view" a useful perspective for strategic management research?”, The Academy of Management Review, Vol. 26 No. 1, pp. 22-40.

Ravallion, M. and Datt, G. (1996), “How important to India’s poor is the sectoral composition of economic growth?”, The World Bank Economic Review, Vol. 10 No. 1, pp. 1-25.

Ringle, C.M., Wende, S., and Becker, J-M. (2015), “SmartPLS 3”, SmartPLS, Bönningstedt.

Sarasvathy, S.D. (2001), “Causation and effectuation: toward a theoretical shift from economic inevitability to entrepreneurial contingency”, Academy of Management Review, Vol. 26 No. 2, pp. 243-263.

Sarasvathy, S.D. (2009), Effectuation: elements of entrepreneurial expertise, Edward Elgar Publishing, Cheltenham, UK.

Schilke, O. (2014), “Second-order dynamic capabilities: how do they matter?”, The Academy of Management Perspectives, Vol. 28 No. 4, pp. 368-380.

Singh, S., Darwish, T.K. and Potočnik, K. (2016), "Measuring organizational performance: a case for subjective measures”, British Journal of Management, Vol. 27 No. 1, pp. 214224.

Siltaloppi, J., Koskela-Huotari, K. and Vargo, S.L. (2016), “Institutional complexity as a driver for innovation in service ecosystems”, Service Science, Vol. 8 No. 3, pp. 333-343.

Skålén, P., Gummerus, J., von Koskull, C., \& Magnusson, P. R. (2015), “Exploring value propositions and service innovation: a service-dominant logic study. Journal of the Academy of Marketing Science, Vol. 43 No. 2, pp. 137-158.

Storbacka, K., Brodie, R.J., Böhmann, T., Maglio, P.P. and Nenonen, S. (2016). “Actor engagement as a microfoundation for value co-creation”. Journal of Business Research, Vol. 69 No. 8, pp. 3008-3017. 
Storbacka, K. and Nenonen, S. (2011), “Scripting markets: from value propositions to market propositions”, Industrial Marketing Management, Vol. 40 No. 2, pp. 255-266.

Storbacka, K. and Nenonen, S. (2015), “Learning with the market: facilitating market innovation”, Industrial Marketing Management, Vol. 44, pp. 73-82.

Taillard, M., Peters, L.D., Pels, J. and Mele, C. (2016), “The role of shared intentions in the emergence of service ecosystems”, Journal of Business Research, Vol. 69 No. 8, pp. 2972-2980.

Teece, D.J. (2007), “Explicating dynamic capabilities: the nature and microfoundations of (sustainable) enterprise performance”, Strategic Management Journal, Vol. 28 No. 13, pp. 1319-1350.

Teece, D.J., Pisano, G. and Shuen, A. (1997), “Dynamic capabilities and strategic management”, Strategic Management Journal, Vol. 18 No. 7, pp. 509-533.

Vargo, S.L. (2010), "Practices, systems, and meaning-making: An introduction to the special section on markets and marketing”, Australasian Marketing Journal, Vol. 18 No. 4, pp. 233-235.

Vargo, S.L., and Akaka, M.A. (2012), "Value cocreation and service systems (re)formation: a service ecosystems view”, Service Science, Vol. 4 No. 3, pp. 207-217.

Vargo, S.L. and Lusch, R.F. (2004), “Evolving to a new dominant logic for marketing”, Journal of Marketing, Vol. 68 No. 1, pp. 1-17.

Vargo, S.L. and Lusch, R.F. (2008), “Service-dominant logic: continuing the evolution”, Journal of the Academy of Marketing Science, Vol. 36 No. 1, pp. 1-10.

Vargo, S.L. and Lusch, R.F. (2011), “It’s all B2B...and beyond: toward a systems perspective of the market”, Industrial Marketing Management, Vol. 40 No. 2, pp. 181-187.

Vargo, S.L. and Lusch, R.F. (2016), “Institutions and axioms: an extension and update of service-dominant logic”, Journal of the Academy of Marketing Science, Vol. 44 No. 1, pp. 5-23. 
Vargo, S.L., Wieland, H., \& Akaka, M.A. (2015), “Innovation through institutionalization: A service ecosystems perspective”, Industrial Marketing Management, Vol. 44, pp. 63-72.

Vargo, S.L., Wieland, H. and Akaka, M.A. (2016), “Innovation in service ecosystems”, Journal of Serviceology, Vol. 1 No. 1, pp. 1-5.

Vij, S. and Bedi, H.S. (2016), “Are subjective business performance measures justified?”, International Journal of Productivity and Performance Management, Vol. 65 No. 5, pp. 603-621.

Wall, T.D., Michie, J., Patterson, M., Wood, S.J., Sheehan, M., Clegg, C.W., and West, M. (2004), “On the validity of subjective measures of company performance”, Personnel Psychology, Vol. 57 No. 1, pp. 95-118.

Wang, C.L. and Ahmed, P.K. (2007), “Dynamic capabilities: a review and research agenda”, International Journal of Management Reviews, Vol. 9 No. 1, pp. 31-51.

Wernerfelt, B. (1984), “A resource-based view of the firm”, Strategic Management Journal, Vol. 5 No. 2, pp. 171-180.

Wilden, R., Akaka, M.A., Karpen, I.O. and Hohberger, J. (2017), “The evolution and prospects of service-dominant logic: an investigation of past, present, and future research”, Journal of Service Research, DOI: 10.1177/1094670517715121.

Wilden, R., Devinney, T.M. and Dowling, G.R. (2016), “The architecture of dynamic capability research: identifying the building blocks of a configurational approach”, The Academy of Management Annals, Vol. 10 No. 1, pp. 997-1076.

Wilden, R. and Gudergan, S.P. (2015), “The impact of dynamic capabilities on operational marketing and technological capabilities: investigating the role of environmental turbulence”, Journal of the Academy of Marketing Science, Vol. 43 No. 2, pp. 181-199.

Zahra, S.A., Sapienza, H.J. and Davidsson, P. (2006), “Entrepreneurship and dynamic capabilities: a review, model and research agenda”, Journal of Management Studies, Vol. 43 No. 4, pp. 917-955. 
Zhao, X., Lynch, J.G. and Chen, Q. (2010), “Reconsidering Baron and Kenny: myths and truths about mediation analysis”, Journal of Consumer Research, Vol. 37 No. 2, pp. 197206.

Zott, C. (2003), “Dynamic capabilities and the emergence of intraindustry differential firm performance: insights from a simulation study”, Strategic Management Journal, Vol. 24 No. 2, pp. 97-125. 
Success in influencing service ecosystems (based on Kumar et al. (2000); Eisenhardt and Martin (2000); Hills and Sarin (2003)):

We have successfully created new markets.

We have been successful in influencing our existing markets so that they work in our favour.

Increased service ecosystem size and efficiency (based on Narver and Slater (1990); Bharadwaj et al. (2005); Baker and Sinkula (1999); Jaworski et al. (2000); Kumar et al. (2000))

The size of our market(s) has increased during recent years.

Our market creates more value to the end customers nowadays than it did a couple of years ago.

Our market uses resources more efficiently (for instance, faster transactions, less waste) nowadays than it did a couple of years ago.

Visioning (based on Eisenhardt and Martin (2000); Day (2011); Zahra et al. (2006); Wang and Ahmed (2007); Kumar et al. (2000); Teece (2007); Jaworski et al. (2000); Hills and Sarin (2003))

We have a good ability to assess the predictability of our market’s future development.

We have a clear vision for how we would like to see our market developing.

We are good at articulating this vision in such a way that it inspires also individuals outside our organisation.

We are good at developing new business initiatives that are 'win-win-win' (i.e., beneficial for us, our customers and our business partners).

We have a useful set of measures that enables us to evaluate whether our market vision is becoming a reality.

Timing (based on Pavlou and El Sawy (2011); Teece (2007); Day (2011); Wang and Ahmed (2007); Jaworski et al. (2000); Kumar et al. (2000); Eisenhardt and Martin (2000); Barreto (2010); Zahra et al. (2006); Hills and Sarin (2003))

We are typically among the first to recognise the value of new information, resources and/or relationships.

We have a good understanding of how easy/difficult it is to change our operating environment.

We are typically among the first to recognise that a major change is about to take place in our operating environment.

We are good at accurately assessing the speed of change in our operating environment.

When timing new business initiatives, we systematically compare the pros and cons of being a first mover versus a follower.

Understanding actor resources and infrastructures (based on Kumar et al. (2000); Storbacka and Nenonen (2015); Burr (2013); Cochoy (2009))

When developing a new business initiative, we analyse what kind of competences our customers need for the new business initiative to succeed.

When developing a new business initiative, we analyse what kind of competences our business partners need for the new business initiative to succeed. 
When developing a new business initiative, we analyse what kind of infrastructure (e.g., broadband width, energy provision, or transportation capacity) is needed for the new business initiative to succeed.

Articulating value proposition (based on Kumar et al. (2000); Pavlou and El Sawy (2011); Jaworski et al. (2000); Hills and Sarin (2003))

We have a well-defined value proposition, which is understood by our customers.

We are good at communicating the total value (economic and non-economic) of our products and/or services to customers.

We systematically evaluate possibilities to redefine our products and/or services in order to better achieve our overall objectives.

We have a good understanding of how our customers make their purchasing decisions.

Engaging with commercial actors $¥$ (based on Jaworski et al. (2000); Hills and Sarin (2003); Kumar et al. (2000))

We see our competitors also as important peers that contribute to the development of our market.

We have a good understanding of the players in our network: their roles, relative power, and the connections between them.

We are good at forming relationships with new commercial business partners (e.g., suppliers, distributors, customers).

Engaging with non-commercial actors and understanding implicit institutions ¥ (based on Jaworski et al. (2000); Hills and Sarin (2003); Kumar et al. (2000); Humphreys (2010))

We are good at forming relationships with new non-commercial business partners (e.g., media, research institutes, governmental organisations, non-governmental organisations).

We actively engage with media to advance our new business initiatives (Note: this excludes paid advertisements).

When developing new business initiatives, we analyse how they are affected by the generally accepted social norms and conventions.

Influencing explicit institutions (based on Granqvist et al. (2013); Jaworski et al. (2000); Kumar et al. (2000); Hills and Sarin (2003); Alvarez et al. (2015))

We have introduced or influenced the terminology that is commonly used in our market.

We influence industry standards (e.g., technological standards, industry self-regulation).

We influence government regulations (regional, national, or international).

External parties such as media and government officials regularly turn to our top managers and experts for advice and/or comments on topics related to our industry.

Notes: All items were measured with a seven-point Likert scale ( 1 = "strongly disagree”, 7 = "strongly agree”).

¥ after the factor analysis, the hypothesized construct 'engaging with other actors' was separated into ‘engaging with commercial actors' (ECA) and 'engaging with non-commercial actors and understanding implicit institutions' (ENCAUII). 